\title{
Za udržitelnost spotřebního chování a životního stylu nese odpovědnost vzdělávání
}

\author{
... a s programem, který jsme společně vytvořili, ji mưže \\ naplnit
}

\section{Jana Dlouhá}

Envigogika 16 (1) - Inspirace /Inspiration

Published/ Publikováno 30. 6. 2021

DOI: $10.14712 / 18023061.623$

\section{Abstrakt}

Článek shrnuje zkušenosti s tvorbou a realizací programu zaměřeného na utváření spotřebních zvyklostí ve vzdělávání a představuje ucelený soubor materiálů pro učitele, aby mohli takový program realizovat.

\section{Abstract}

The article reflects experience with developing and implementing a program focused on the formation of consumer habits in the context of formal education and presents a comprehensive set of materials for teachers to implement such a program. 


\section{Úvod - o ekonomickém sobectví, nebo naopak spolupráci}

Co jsme se naučili během krize Covid-19? Kromě jiného i to, že na sobě závisíme, musíme si pomáhat a vzájemně důvěřovat. Ledacos jde řešit systémově, ale vzájemná podpora pomáhá nejen tam, kam systém už nedosáhne (což jsou všechny mezilidské vztahy) - je to i pojistka i proti jeho selhání. Pokud se zavřeme ve svých domovech a s vnějším světem si budeme vyměňovat jen to nejnutnější, my sami si své základní potřeby z části uhájíme, nejspíš ale ohrozíme ty druhé. Pokud se jim dařit nebude, svět přijde o výrobky nebo služby, které si vzájemně nabízíme, abychom si život zpř́ijemnili - a které tak ztělesňují dobrou vůli. Zbydou (ekonomické) vztahy jako nástroj ovládání, profitu na úkor někoho nebo něčeho. Za této (snad již minulé krize) jsme viděli v přímém přenosu, že nakupování není pouhou cestou $k$ uspokojení nás samých, je také prostředkem vzájemné podpory. Tím, že zajdeme do nedaleké hospůdky nebo na představení nejbližšího divadla, pomůžeme jejich (ekonomickému) přežití, a př́ště je najdeme zase tam, kde jsme byli zvyklí. Když budeme všichni nakupovat jen $v$ supermarketech (a nebudeme dělat nic jiného), zmizí všechny podniky nebo kulturní zařízení, které jsou zde pro radost.

Mohli jsme si tak vyzkoušet, že to, jak se ekonomicky chováme, podobu ekonomiky formuje - budeme ji mít takovou, jakou si ji (všichni dohromady) uděláme. Společně ji můžeme ovlivnit tak, aby byla napríklad odpovědná nebo udržitelná. Je totiž přesně taková, jako jsme my sami - a jde tedy o to, abychom se v současném světě neomezených možností dokázali správně rozhodovat. Pokud možno všichni, nezávisle na výši př́ijmů.

To je i základní poznatek, který by se měl promítnout do vzdělávání. Může totiž změnit náš celkový pohled na ekonomický systém. Už ne soubor ekonomických zákonitostí, vůči kterým je člověk bezmocný - ale naopak jsme to my, kdo je utváríme. Jenomže to se o roli jednotlivce $v$ ekonomickém systému ve školách nedozvíme. I když by takové poznání mohlo vést $k$ tomu, že se tento jednotlivec emancipuje, přestane podléhat vnějším vlivům, začne si svá rozhodnutí rozmýšlet $s$ ohledem na své dlouhodobé zájmy... na svůj život, jaký by ho chtěl $v$ budoucnosti mít.

\section{Co jsme chtěli změnit - program vzdělávání k odpovědné spotřebě...}

Na začátku tak byla otázka: "Učí se v našich školách to, co je potřeba pro život?" $Z$ dětí přece nevyrostou jen profesionálové: např́klad právníci, inženýrí, úředníci, nebo třeba sestřičky v nemocnici. Budou si muset také zařídit svůj osobní život: vybrat místo k bydlení, pořídit nezbytné vybavení, denně pak užívat předměty běžné potřeby, a také je docela často nakupovat. Kde ale mají získat znalosti a dovednosti potřebné $\mathrm{k}$ tomu, aby jejich drobná rozhodnutí ohledně uspokojování těchto potřeb nakonec ve svém součtu nepoškozovala přírodu a vztahy lidí ve společnosti? Škola se tomuto tématu do hloubky nevěnuje, a tak si děti své představy většinou utvářejí přirozenou cestou: pod vlivem rodiny, kamarádů, kterým se často chtějí především vyrovnat, a v tvorbě jejich názoru mívají důležité slovo $i$ reklamní kampaně, protože jinde podrobné informace o výrobcích a spotřebních možnostech nejsou k mání.

Odpovědná spotřeba je přitom obsahem Cíle udržitelného rozvoje č. 12 (Odpovědná, nebo také udržitelná výroba a spotřeba, SDG 12), a právě vzdělání může připravit širokou veřejnost na to, aby jej svým každodenním spotřebním chováním naplňovala. Chovat se odpovědně přitom nemusí znamenat, že se smíríme se snížením kvality našeho života právě naopak. Tím že se o spotřebě naučíme přemýšlet, můžeme objevit nové způsoby, jak svůj život naplnit nejen z hlediska základních potřeb, ale taky př́jemnou zábavou nebo 
dokonce smyslem. Např́íklad v okruhu sdílených zájmů můžeme najít nové přátele; nakonec zjistíme, že ke svému štěstí nepotřebujeme spoustu předmětů materiálního světa - ty nás naopak zahlcují, zaplňují náš prostor i čas. Když své potřeby a především touhy takto přehodnotíme, pak taky finance, které běžně máme nebo které chceme $v$ budoucnu utrácet, můžeme použít nápaditě a/nebo s trochu větším nadhledem, a tím také podpořit ekonomiku vycházející z hodnot udržitelnosti. Toto hlubší zamyšlení nad vlastním životním stylem je ovšem nakonec prospěšné nejen společnosti, ale i každému jednotlivci, protože ten si pak může vědomě uspořádat své záležitosti a stanovit si vlastní dlouhodobé cíle. To je ovšem ideál, ke kterému náš vzdělávací systém zatím př́liš nepřispívá.

\section{....a jak jej vytvořit}

Představme si ovšem, že by škola na sebe vzala úkol vést k odpovědnému spotřebnímu chování a životnímu stylu, systematicky vzdělávat každého jedince $v$ každém věku tak, aby se dokázal uvědoměle rozhodovat o malých i velkých věcech a činnostech, jež musí nebo chce každodenně provádět. Co by $\mathrm{k}$ tomu bylo zapotřebí: především stanovit obecné cíle takového programu vzdělávání - je jimi schopnost orientovat se ve spotřební nabídce, a hlavně se přitom zaměřit na určité hodnoty, aby taková spotřeba "konzumenta" nejen uspokojila, ale měla i co nejnižší environmentální a sociální dopady. Etické principy jsou tedy prvním východiskem, které vzdělávání tohoto typu musí nejprve kriticky zkoumat a poté trvale zakotvit. Za druhé je nutné (na tomto základě) najít konkrétní vzdělávací cíle, které tyto obecně stanovené zásady naplňují. Pro ty pak navrhnout vhodné pedagogické př́stupy a rozpracovat je do podoby metodických materiálů tak, aby učitelé sami již nemuseli všemi předchozími kroky procházet. To je nutný postup, díky kterému mohou být odborné poznatky, nezbytný stavební materiál každého vzdělávání, "přeloženy" do řeči pedagogiky, a uzpůsobeny pro nehotovou mysl a nezralý názor tak, aby byly nejen pochopitelné, ale i přijatelné. Teprve tak bude možné postupně tvarovat lidskou bytost, umožnit jí všestranný rozvoj, při respektu k hodnotám důležitým pro lidstvo a př́rodu.

Ne každý ovšem dokáže obojí: přemýšlet tvořivě, empaticky procházet kroky od návrhu programu po uskutečnění, a nakonec ještě sbírat a vyhodnocovat data o jeho dopadu na některé složky osobnosti účastníků, např́klad jejich znalosti či (emocemi podložené) názory. Přestože zamýšlet se nad hodnotami, které formují náš každodenní život, je samozřejmě poučné, často na to není čas; nároky školního roku bývají neúprosné. A tak jsme postavili mezioborový tým ${ }^{1}$, který pak rozpracoval téma odpovědné spotřeby z různých hledisek - tak, aby bylo snadné přejít od slov k činům, a vytvořené materiály bylo možné rovnou použít $v$ hodinách. Kromě tématu samotného při tom měli jeho protagonisté vždy na mysli děti - žáky, studenty, kteří by měli mít možnost zažít názorné vzdělávání, které je nyní bude všestranně rozvíjet, a jehož výsledky jim $v$ budoucnosti dobře poslouží $-v$ tomto případě je navedou k přemýšlení o své každodenní životní praxi. Samotné učení by pak mělo být aktivním zkoumáním skutečnosti, kreativním procesem, který odhaluje to, co je skryto, co ale přesto naši skutečnost utváŕí.

\footnotetext{
1 Šlo o tým v rámci projektu TL01000117 „Odpovědná spotřeba - podklady pro vzdělávání k udržitelnému životnímu stylu" řešeného v rámci programu Technologické agentury ČR na podporu aplikovaného společenskovědního a humanitního výzkumu, experimentálního vývoje a inovací ÉTA v letech 2017-2021.
} 
Níže uvádíme přehled všech materiálů, které v projektu vznikly - zdůrazňujeme přitom inovativní aspekty jednotlivých témat i některé další souvislosti toho, jak jsou uchopeny.

\section{Co obsahují podklady pro učitele a další zájemce o toto téma?}

Samotné znalosti k obratu $v$ myšlení a zvyklostech nevedou, a tak jsou kromě toho vzdělávacím a výchovným cílem především kompetence působící na všechny složky osobnosti. Tak o vzdělávání k Cílům udržitelného rozvoje přemýšlí také kolektiv expertů pod hlavičkou UNESCO, kteří navrhli klíčové kompetence udržitelnosti a rozpracovali je pro každý z Cílů SDGs². Jimi navržený program má ve svém celku vést ke změně - zažitých představ, ale i chování, a v širším důsledku i vztahů v menším společenství (například třídě a škole), což se do budoucna může projevit i v měřítku větším.

Takto je postavena Metodika vzdělávání k odpovědné spotřebě a životnímu stylu ${ }^{3}$, která má učitelům pomoci utvářet spotřební zvyklosti dětí - nejen při jejich každodenním rozhodování, ale s ohledem na volbu celého způsobu života, tzv. životního stylu. Představuje hlavní principy takového vzdělávání i postupy při jejich uplatnění v praxi vzdělávání, a to na úrovni mateřských škol, základních škol 1. a 2. stupně a středních škol. Metodika vychází $z$ Odborných podkladů (které představují nové vědecké pojmy a koncepty odpovědné spotřeby); zohledňuje pedagogické zásady vzdělávání kudržitelnosti s důrazem na transformativní učení; využívá přístupy zaměřené na osobnostní rozvoj ve všech doménách učení: kognitivní, sociálně-emocionální a behaviorální) a diskutuje uplatnění v konkrétních vzdělávacích programech. $V$ této praktické rovině ukazuje, jak téma odpovědné spotřeby začlenit do vzdělávacích programů na různých úrovních (od MŠ po SŠ), a upozorňuje, na co klást důraz a čeho se přitom vyvarovat. Podává návod na vytvoření programu a jeho uskutečnění - od stanovení vzdělávacích cílů pro různé věkové kategorie, přes metodické využití odborných podkladů a dalších zdrojů informací, až po hodnocení výsledků takového výchovného/vzdělávacího působení; diskutuje přitom možnosti začlenění do formálního vzdělávání. Na príkladu konkrétního programu, který byl pilotně ověřen, tak ukazuje způsoby uplatnění teoretických východisek v praxi. Metodika shrnuje množství dalších podkladů, které učitelé mohou využít jako zdroje informací nebo metodické pomůcky odkazuje na ně $v$ textu.

Jedním z hlavních materiálů pro učitele, který je využitelný přímo jako podklad pro práci v hodinách, jsou Metodické listy pro odpovědnou spotřebu - zde jsou představeny 4 navazující dvouhodinové lekce pro každý stupeň škol (MŠ, I. a II. stupeň ZŠ a SŠ; $\checkmark$ kontextu MŠ se jedná o 4 navazující projektové týdny). Témata lekcí zůstávají pro každý stupeň škol stejná s tím, že spirálovitě stoupá náročnost obsahu lekcí podle věku dětí, žáků nebo studentů. Vedle tohoto základního rozvržení programu a inspirativních postupů pro jeho realizaci jsou $k$ př́mému využití $v$ hodinách $k$ dispozici též Pracovní listy. Další Metodické podklady slouží jako efektivní připomenutí toho, jaké postupy v programech vzdělávání $k$ odpovědné spotřebě použít a jak si na základě toho naplánovat, co za materiály a informace $\mathrm{k}$ tomu budou zapotřebí. Spolu se všemi dalšími materiály, které například

\footnotetext{
2 UNESCO. (2017). Education for Sustainable Development Goals Learning Objectives. UNESCO. http://unesdoc.unesco.org/images/0024/002474/247444e.pdf

${ }^{3}$ Dlouhá, J., Kroufek, R., Neprašová, S., Jančaříková, K. (2021) Metodika vzdělávání k odpovědné spotřebě a životnímu stylu. Certifikováno MŽP pod číslem jednacím MZP/2021/320/476. Centrum pro otázky životního prostředí UK, ISBN: 978-80-87076-28-6. Online dostupné na http://odpovednaspotreba.cz/metodika/.
} 
specifikují cíle vzdělávání k odpovědné spotřebě dle věkových kategorií nebo začleňují téma spotřeby do Rámcových vzdělávacích programů, pomohou zájemcům z řad (nejen) učitelů realizovat programy vzdělávání k odpovědné spotřebě v praxi.

Nové poznatky o (udržitelném) spotřebním chování, ekonomických procesech, které je umožňují, i širších souvislostech, například limitech planety Země a co pro nás znamenají, nebo by měly znamenat, přinášejí Odborné podklady k odpovědné spotřebě ${ }^{4}$, které jsou souhrnem odborných informací $k$ dílčím tématům odpovědné spotřeby. Jde o 15 podrobně zpracovaných témat, např́klad odpovědné spotřebitelské chování nebo cirkulární ekonomika, které by měly sloužit pedagogům k rozšíření informací o tématu a vybavit je odbornými informacemi do výuky. Představují jisté "body obratu" v (nejen) ekonomickém myšlení, a s tímto cílem byly také zařazeny do jednotlivých lekcí v rámci Metodických listů - mají především vést k hlubšímu zamyšlení nad tím, co jsme až dosud považovali za samozřejmé.

Pro přehlednost jsou všechny materiály shromážděny na webu Odpovědná spotřeba, www.odpovednaspotreba.cz. To učitelům umožňuje např́klad převzít pracovní listy určené pro určitý stupeň školního vzdělávání a pouze je mírně upravit pro podmínky své vlastní školy a třídy. Dưležité je mít taky po ruce nástroj k hodnocení - umožňující posuzovat pokrok žáků nebo studentů $v$ tom, co by se $v$ programu měli naučit, přičemž pouhé znalosti jsou jen prvním krokem k zamýšlené změně vzorců chování. Všechny tyto nástroje jsou zde učitelům po ruce tak, aby dokázali propojovat odborné poznatky s metodickými, našli vhodná témata a přístupy, které jsou využitelné při aktivitách $v$ konkrétním školním prostředí, a dokázali pracovat $s$ dalšími zdroji (protože trocha pedagogické teorie nikoho nezabije).

\section{Závěr: proč vytvářit vzdělávací programy pro školy společně?}

Programy environmentální výchovy (kam spadá i vzdělání pro udržitelný rozvoj) dnes navrhují většinou experti nevládních organizací; akademická pracoviště postupně našla svou roli $v$ tom, že hodnotí výsledky takto vzniklých programů nejrůznějšího zaměření a doporučují, jak by se dalo působit účinněji. Skutečně kreativní design těchto programů tak vzniká spíše na pomezí - ve spolupráci vysokoškolských učitelů, většinou však na půdě spř́zněné nevládní organizace, kde vládne svoboda experimentovat a je tam i prostor pro debaty o prínosech a slepých uličkách. Pravidla akademického diskurzu jsou neúprosná, kreativní hledání nových možností se připouští, pouze když se najde poměrně exaktní metoda vyhodnocení jejich výsledků. Skutečná pedagogická reforma, která by poskytla svobodu se vzdělávacími tématy zabývat svobodně - tak, aby výsledkem byla skutečná vzdělanost - na obzoru není. Co s tím?

Rozhodli jsme se, že se pokusíme tuto situaci změnit. Projekt, který jsme navrhli, zapojil všechny, kdo by mohl hrát roli v návrhu programu, jeho designu (jak jsme již naznačili a stručně popisujeme i dále), při jeho uskutečnění a nakonec i při evaluaci. Postavili jsme tým složený $z$ akademiků (odborníků na zvolené téma a pedagogů), a lidí z praxe, $\checkmark$ tomto prípadě z nevládní organizace Tereza, z.ú. Ti pak měli stát v „první linii" a čelit jak našim odborným nárokům, tak také učitelům, kteří měli tak trochu naslouchat teoretickým

\footnotetext{
4 Dlouhá, J., Kapitulčinová, D., Šindelářová, I., Kafková, D., Dlouhý, J. (2021) Odborné podklady k odpovědné spotřebě. Centrum pro otázky životního prostředí UK, ISBN: 978-80-87076-27-9. Online dostupné na http://odpovednaspotreba.cz/odborne-podklady/
} 
úvahám a spolupracovat na tvorbě programu, především jej však zkoušet $v$ praxi. $\vee$ této součinnosti jsme program vytvořili a zároveň o tomto postupu průběžně přinášeli zprávu akademické obci - věděli jsme, že jen tato sdělená zkušenost může být základem pro jeho další rozvíjení. Za více než tři roky práce tak vznikl program pro všechny stupně škol, a velmi ucelený soubor materiálů pro jeho realizaci. Ty ted' nabízíme k širokému využití - a pokud vám budou naše podklady užitečné, prosíme o zpětnou vazbu, která umožní jeho další zlepšování.

V Praze začátkem letních prázdnin 2021

sepsala Jana Dlouhá, vedoucí projektu 